\title{
Effect of Fundamental Stage Training Program Based on LTAD Model Toward Basic Swimming Skills
}

\author{
Z. Arifin, Asep Angga Permadi, Riri Agustina Pratiwi \\ Physical Education, Faculty of Islamic Education and Teacher Training, \\ Garut University, Indonesia \\ z.arifin.pjkr@uniga.ac.id
}

\begin{abstract}
The purpose of the study is to find the effect of a fundamental stage training program on basic swimming skills. Pre-experimental design with one-group pretest-posttest design was employed as the research method. The population of this study was 20 students of TK IT Al-Wasilah who are 6 years old. Meanwhile, the sample of the study was taken as a whole of the population (saturated sample). The research instrument was a basic swimming skills test. The data obtained will be analyzed using paired sample t-test analysis. The result showed that there is a significant Effect of Fundamentals Stage Training Program Based on LTAD Model towards Basic swimming skills.
\end{abstract}

Keywords: fundamental stage, training program, LTAD model, basic swimming skill

\section{INTRODUCTION}

The combination of physical education with the LTAD model encourages students to engage in life-long activities and ensure the students to learn basic movements which are in line with student growth and development. Skills are firstly introduced at the FUNdamental stage or before the age of 11 (female) and 12 (male) [3]

Physical education at schools must teach basic skills and sports skills for the students' active lifestyles which are in accordance with the LTAD model. Equipped with the right skills and positive experience, students will not experience obstacles and difficulties in carrying out any activity [2].

The LTAD model increases students' culture of participation, because students have been prepared starting from playing to being winners. In addition, it can also help students in creating things that allow them to achieve optimal potential in each appearance [2]. LTAD covers every aspects of physical development, and students must be adequately prepared to sports life. LTAD helps to grow a culture of lifelong participation by highlighting the value of sports in improving health and welfare.

Some stages of the LTAD model in learning swimming sports skills include: the stages of FUNdamentals, learning to train, training to train, training to compete, training to win, and retirement / retention [4]. For swimming learning in PreSchool, the FUNdamental stage and the materials taught are basic swimming skills including: water orientation, water entry, breath control, buoyancy, arm propulsion, leg action and combined movement [5]. In addition, the learning process must be fun, through games, singing, or the combination of the two

In Indonesia, especially in Garut Regency, swimming learning in Pre-School tends to be traditional and prioritizes technical skills rather than seeing other aspects, such as playing or singing. However, in the level of FUNdamental, the learning process must be delivered in a fun way. As a teacher, I think there are still lacks references regarding the most appropriate program for teaching at that stage. In fact, the swimming learning programs are delivered like at an adult level.

That is why, the researcher was intrigued to create a particular training program to be applied at the FUNdamental stage for Pre-School levels. So that this program can be later be spread, or even further developed by physical education teachers at the school. This learning program is based on playing, singing and a combination of both. In making this learning program, the researcher can pay attention to the principles of the LTAD model. This study aims to investigate the effect of the fundamental stage training program towards basic swimming skills.

\section{Methodology}

This research uses the experimental method. The method is used to test the hypothesis to find out the influence of the independent variable (treatment) and to test the changes caused by the treatment under tightly controlled conditions $[6,7,8]$. The research design used a Pre-Experimental Design in which there was one group given the initial test, treatment, and final test. $[8,9,10]$

The treatment was given to 20 students of TK IT AlWasilah Garut. Meanwhile, the sample is taken as a whole from members of the population (saturated sample). The research instrument is adopted from the preschool students' swimming skill instrument [11]. This instrument consists of 31 questions with 7 indicators, namely the introduction to the water, entering the pool, controlling the breath, floating, pushing the arms, leg movements, and complete movements/complete swimming.

Research procedure includes: Pre-test uses basic preschool swimming skills instruments to all research samples. The training program lasts for one semester or 16 sessions. Every week only one session, there is a session for 30-60 minutes (LTAD Model). The training program consists of three parts, namely preliminary activities, core and closing. The post-test uses basic pre-school swimming skills instruments to research samples.

Pre-test and post-test data were analyzed by using the applications of Microsoft Excel and SPSS 16 through several stages: First, the analysis prerequisite test using the normality and homogeneity data. Second, this statistical hypothesis test is conducted to obtain conclusions from the 
research problem by looking at the hypothesis test using paired sample t test.

\section{RESULTS AND DISCUSSION}

\section{A. LTAD Model and Fundamental Stage at School}

The LTAD Model is an athlete's coaching through students' growth and development. This model seems to be very possible to be applied and even to be combined with the physical education curriculum, especially to be implemented in swimming learning in Pre-School

The FUNdamental Phase is the initial stage of the LTAD Model which is applied in swimming learning in PreSchool. This stage studies students' basic swimming movements, breathing, sliding, foot movements, etc. The training program is delivered by playing and singing methods, as well as a combination of both. This is very helpful for clubs/associations in fostering swimming athletes in the Learning to Train, Training to Train to the stages of Retirement/Retention [4].

The LTAD model provides stages of learning that are appropriate for students' level of development and age. The instructions and the programs are the clear things that must be given to students. All of that is expected to be a strong foundation for students as a provision of future life in doing sports skills, because students will not feel difficulties in learning any sports skills because they have learned the LTAD model at school [3].

\section{B. LTAD Model in All Aspect}

LTAD models can help students to have sports skills through direct participation in learning, absolutely by paying attention to students' growth and development. In other words, skills are not automatically possessed by students without the learning process [12].

This LTAD model has prepared some stages, such as FUNdamental, Athlete performance, and the activities of a students' lifetime. There are many benefits from participating in sports activities, such as physical and mental health, psychosocial development and motor skills [13]. Some other advantages of the LTAD model, students can have physical, mental, emotional, and cognitive development skills.

Through the LTAD model, students will have what is called physical literacy, which means that students who learned the model will develop movement skills and sports skills. Thus, that increases students' confidence, especially when doing other sports activities without finding difficulties. It is different from students who do not apply the LTAD model, because there is no FUNdamental stage but just jumps to a higher level. So that students will have a some difficulty in learning [14].

\section{Fundamental Stage and Basic Swimming Skills}

At this FUNdamental stage, students are expected to have confidence while in swimming pool. Learning materials/programs are related to basic motor skills and also the introduction of water without eliminating a fun and playful learning atmosphere. The swimming program includes water orientation, water entry, breath control, buoyancy, arm propulsion, leg action, and combined movement [14].

It is important to consider that learning programs that are provided with a pleasant atmosphere is better than those that are competitive. Playing games and singing are considered better than using formal learning. Students can respond well through games and singing. They do not know what they are learning although they themselves are learning skills [15].

It is very important for children that the swimming learning program at this stage should be in the form of games, pictures and also singing, because during the program the learning process occurs and it can also affect the students' development. Students' ability to imagine an object is another natural ability possessed by a student. Because of that, students can increase their willingness to participate in learning programs that have been delivered by their teacher.

\section{CONCLUSION}

The result showed that there was a significant effect of fundamentals stage training program based on the LTAD model towards basic swimming skills.

\section{ACKNOWLEDGMENT}

I wish for the success of Lambung Mangkurat University as the organizer of this publication. I also thank the Physical Education Study Program, Faculty of Islamic Education and Teacher Training, University of Garut.

\section{REFERENCES}

[1] G.T. Moote, J.S. Wadorski, The acquisition of life skills through adventure-based activities and programs: a review of the literature, Adolesence, 1997.

[2] S. Robetson, R. Way, Long Term Athlete Development. Coach Report, Vol. 11 (3).

[3] I. Balyi, R. Way, C. Higgs, S. Norris, C. Cardinal, Sport for LifeLong-Term Ahlete Development papert 2.1, Canada: Sport for Life Society, 2016

[4] Amateur Swimming Association (ASA), The swimmer Pathway: Long Term Athlete Development, Loughborough: ASA, 2003

[5] J.S. Langendorfer, B.D. Lawrence, Aquatic Readinesss. Developing Water Competence in Young Children, California: Human Kinetics Publisher Inc, 1995

[6] Riduwan, Skala Pengukuran Variabel-variabel Penelitian, Bandung: Alfabeta, 2009

[7] Sunarti, Subana. Strategi Belajar Bahasa Indonesia Berbagai Pendekatan, Metode, Teknik, dan Media Pengajaran, Bandung: Pustaka Setia, 2009.

[8] Sugiyono, Metode Penelitian Administrasi, Bandung: Alfabeta, 2001.

[9] S. Arikunto, Prosedur Penelitian Suatu Pendekatan Praktik, Jakarta: Asdi Mahasatya, 2006.

[10] A. Noor, Manajemen Event.,Bandung: Alfabeta., 2013.

[11] E. Susanto, Pengembangan Tes Keterampilan Renang Anak Usia PraSekolah. Jurnal Penelitian dan Evaluasi Pendidikan, vol. 20(2), pp. 160-161, 2010.

[12] D.L. Gallhue, Fundamental Movement Experiences for Children, New York: Wiley, 1982

[13] I. Balyi, Sport System Building and Long-term Athlete Development in British Columbia, Canada: SportsMed BC, 2001.

[14] H.R. Banack, G.A. Bloom, W.R. Falco, Promoting Long Term Athlete Development in Cross Country Skiing Through CompetencyBased Coach Education: A Qualitative Study, International Journal of Sports Science \& Coaching, Vol. 7 (2), 2012.

[15] M.T. Frankish, Better Understanding the Adoption of the Long-Term Athlete Development Model: Case Analyses of Cross-Country Ski Coaches, Canada : University of Ottawa, 2001 